\title{
THE CONCEPT OF HOPE IN THE WESTERN AND EASTERN PERSPECTIVE
}

\author{
1*Azizunisak Hidayati Wahyuna, ${ }^{2}$ Susi Fitriana \\ 1, 2STIT Karya Pembangunan Paron, Ngawi, Indonesia \\ 1*azizunisak.hw@gmail.com; 2susimahira55@gmail.com
}

\section{ARTICL E IN FO}

\section{Article history}

Received 11/1/2020

Revised 9/2/2020

Accepted 10/4/2020

Keywords

Hopes

Western Perspective

Eastern Perspective

Psychology

Islamic Hope

\section{ABS TRACT}

\begin{abstract}
Hope is a defining element of effort, social change, awareness, and reason. The object of hope is a life that more complete, a life that greater, deliverance from eternal boredom, or for salvation or for revolution. Hope is paradoxical. Hope is a form of feeling associated with the time dimension. Everyone has different hope in life. However, sometimes we may find people with no hope. Humans who have no hope known as passive-apathetic people, while people who have hope as people who will always make themselves optimistic-active.
\end{abstract}

This is an open access article under the CC-BY-SA license.

\section{INTRODUCTION}

The rapid development of technology and information facilitates human access to meet all their needs. With the techniques that humans developed, they seemed to have been able to answer decisions for their future (Fromm, 2005) see also (Widarto, 1990). Marcuse argued that domination perpetuates and extends itself not only through technology but also as the technology, and at least gives greater legitimacy from the growing political power, which absorbs all parts of culture (Marcuse, 1959).

Based on scientific studies, humans find the knowledge that they can use to rule the world. This situation has an impact on focusing only on technical issues and material consumption and then causes humans to lose the relationship between themselves and their lives. The loss that mentioned before is the loss of religious beliefs, human values, and loss of human ability to experience the deepest feelings; pleasure and sadness (Fromm, 1952)

Postmodern philosopher Jean Baudrillard stated that globalization of the world causes changes in values. This era marked by the disappearance of normative boundaries, everything that is "taboo" or sacred disappeared, all problems and information became public sphere that is free to be discussed and consumed in general (Baudrillard, 1996). Issues that in the social and religious perspective 
appertain to taboo and sacred areas currently deconstructed massivelypermissively.

Humans are seen only as a symbol of statistical figures, which present without feelings and conscience. The human soul reduced as deterministic mechanical robot figures on market forces, industrial machinery, and bureaucratic mechanisms. Lewis Mumford, in the book The Myth of Machine (Mumford, 1967), provided a new perspective and discussion about the future by analyzing the roots of the past. This main phenomenon, according to Mumford, is called megamachine (Chaer, 2016).

The mega-machine concept talks about machines as an organized and uniformed social system so that society functions as machines and humans as their parts, with a total organization in the form of an organization along with the increase in command, power, forecast, and control. Humans are present with the totality of uniformity of motion and behavior; deviation that occurs has no place because it violates the rhythmic laws of the machine itself. Humans move with rhythmic characteristics like a machine; humans no longer have the opportunity, giving appreciation to themselves as homo esperans, who are people who hope.

\section{METHODS}

This research uses library research by searching books related to the subject matter discussed descriptively (Singarimbun, 1989). Concept research or literature carried out by conducting a careful study of the literature relating to the subject matter discussed (Hadi, 1980). The subject of the study regarding the expectations of a Western perspective, presented by Fromm and Snyder and Eastern perspectives, which sourced from Islamic teachings. Following its meaning, this study seeks to present the social world and its perspectives in terms of concepts, behaviour and perception (Moleong, 2005).

The technique used to analyze research data is to form content analysis, using whatever method used to conclude an effort to find the characteristics of messages and objectively and systematically. Thus the process used is an induction so that it does not rely on the existence of theories or hypotheses because in qualitative research it works to understand or interpret data that has been categorized (Mahfudz, 2005).

Efforts to make this research focused and systematic, this research was carried out through methodological steps as follows: first, tracking and collecting data relevant to the subject of the study, namely about expectations according to Western thinkers and Islamic thinkers. Therefore, the reference book used refers to the book that contains the theme of the study of hope in psychology, especially positive psychology. Second, processing the data collected to be classified based on the similarity of themes and problems, then given a distinctive mark to facilitate the editing process. Then the data is linked and compared with each 
other and placed it in a logically abstract pattern. The next step is to identify and classify data in variables so that there is a logical and systematic relationship between one another. Third, to analyze the data, using a descriptive-analytic approach to study the concept of expectations based on Western thought, in this case, represented by Fromm and Snyder and expectations according to Islam, represented by al-Jauzi, Ibn Taimiyah by providing an overview and conducting analytical studies in expressing concepts about hope.

\section{RESULT AND DISCUSSION}

\section{A. Hope from Eric Fromm's Perspective}

The wealth of modern human understanding is currently very limited when dealing with the understanding of human behavior reality. Humans often stutter in capturing messages or intentions of the words, deeds, and gestures of others in everyday life. Sophisticated postmodern technology has made ghosts in the middle of human civilization. Life becomes very mechanistic. Emotional conditioning instruments control human feelings. Although in this process humans are given a variety of entertainment, they are passive, dead like losing their feelings. During the first industrial revolution, humans replaced muscle energy, from the human body and animals, with mechanical energy such as steam and electricity. During the second industrial revolution, the human mind replaced by machines (Fromm, 1968).

The writing of Karl Marx greatly influenced Fromm, especially the book The Economic and Philosophical Manuscripts (Marx, 1844). This Karl Marx work was translated into English by T.B. Bottomore, contained in the book Marx's Concept of Man by Fromm (1961). Fromm compared the ideas of Freud and Marx, explored their contradictions, and tried to synthesize. The intended contradiction is that a person is both a part but, at the same time, separate from nature, an animal but also a human being (Fromm, 1962).

Fromm viewed Marx as a more superior thinker than Freud and used psychoanalysis primarily to fill gaps in Marx's thinking. Fromm (1959) wrote a very critical and even polemical analysis of Freud's personality and influence, in stark contrast to the praise words he gave to Marx. Although Fromm could be appropriately called a Marxian personality theorist, he preferred to be called dialectical humanist.

The underlying theme of all Fromm's writings is a person who feels lonely and isolated because he separated from nature and other people. Not all animal species determined this state of isolation; it is a typical human situation. The educational background of Freud's psychoanalytic teachings and the influence of Karl Marx, Karen Horney, and other socially oriented theorists, Fromm developed personality theories that emphasized the influence of sociobiological, historical, economic, and class structure factors. In his book, Escape from Freedom, Fromm developed the thesis that humans become 
increasingly free from century to century, so they also feel lonely. So, freedom becomes a negative state from which humans escape (Fromm, 1941).

Hope, according to Fromm, is a decisive element in every effort to bring social change toward greater life, awareness, and reason. The object of hope is a more complete life, a more excellent life, a release from eternal boredom, or for salvation, or revolution. According to Fromm, in building hope, there will be some obstacles, stagnation in the process of construction of human life. At this moment, not only requires ansich faith but also requires an attitude of courage. Courage to try, take risks, and courage to fight for ideals.

According to Fromm, courage is also synonymous with fortitude. However, fortitude is often understood by some humans as an ambiguous expression. The word stoicism, which is synonymous with courage, is more often used to express the courage to die rather than the courage to live. True fortitude is the ability to struggle, to combine expectations and beliefs by transforming them into rational optimism (Shanahan, 2020) to build expectations (Bailey et al., 2007). Hardiness must also be understood in the context of the fearless aspect.

\section{B. Hopes from Charles R. Snyder's Perspective}

The main purpose of human life is happiness, which is supported by hope. Even though someone has a guarantee about the future, but with hope, it will become something better. Hope means going on, thinking, "I can do this". It brings inner strength, confidence, the ability to do what someone can do honestly and transparently (Dalai Lama, 2013).

Snyder believed the theory of hope influences positive thinking. According to him, hope is the overall ability of individuals to produce pathways to achieve desired goals, along with the motivation they have to use these pathways. Hope is based on positive expectations in achieving goals. Snyder, Irving, and Anderson stated that hope is a positive motivated state and based on an interactive relationship between agency (energy that leads to goals) and pathway (plans to achieve goals). Snyder also describes hope as a cognitive set based on the reciprocal relationship between agency and pathway (Snyder et al., 2001), see also (Chaer \& Febrianingsih, 2018).

Snyder conceptualized expectations into two components; the ability to plan a path to achieve the desired goals and agency or motivation to use that path. Based on this concept, expectations will be stronger if expectations are accompanied by goals that are valuable and can be achieved, not something that is impossible to achieve. This is where the emphasis of the theory of hope sparked by Snyder, that hope can be said as hope if he has goals that can be and not impossible to achieve.

Snyder's theory of hope also pays attention to the role of obstacles, stressors, and emotions. When encountering obstacles that hinder the achievement of goals, individuals will assess the condition as a source of stress. Based on the 
postulate theory of hope, positive emotion is a result of perceptions about the success of achieving goals. Conversely, negative emotion reflects the failure to achieve goals, both those who experience obstacles and those who do not. Therefore, the perception of the success of achieving goals will encourage the emergence of positive and negative emotions. Then this emotion will act as reinforcing feedback.

Synder divided the components contained in hopes into three things: Goal, Pathway Thinking, and Agency Thinking. A goal is the target of the stages of mental action that produces cognitive components that aim to provide the endpoint of the stages of individual mental behavior (Langlois, 2020). This goal must also have sufficient value to reach the individual's conscious mind to make hope raises higher. In other words, these goals must have the possibility to be achieved but also contain some uncertainties (Snyder \& Lopez, 2007).

At the end of the continuum of certainty, absolute certainty is a goal with a $100 \%$ chance of achievement, but such goals no longer require hope. Expectations will develop well in the condition if goals have a medium level of possible achievements. These goals can also be approach-oriented in nature (something positive that expect to occur) and preventive in nature (something negative that you want to stop so that it does not happen again). The goals are also various depends on the level of likelihood to achieve them. Even a goal that seems impossible to achieve in time can be achieved with greater planning and effort.

Next is the pathway thinking, which is a process where the individual must see himself as someone who has the ability to develop a path in order to achieve the desired goal. This pathway thinking marked by internal message statements such as "I will find a way to solve it!" Pathway thinking includes thinking about the ability to produce one or more useful ways to achieve the desired goals.

Finally, agency thinking, means the capacity to use a path to achieve the desired goals. The agency reflects the individual's perception that he can achieve his goals through the paths he thinks. The agency can also reflect the individual's assessment of his ability to survive when he faced obstacles while achieving his goals. People who have high hopes use self-talk like "I can do this" and "I cannot stop here".

The agency and pathway components are related to one another. Mutually reinforcing, influencing, and being influenced on an ongoing basis in the process to achieve the goals. According to Snyder's theory of hope, these two components are indispensable. However, if one of them failed to achieve, then the ability to maintain the achievement of the goal will not be sufficient. The components of pathway thinking and agency thinking are complementary, reciprocal, and positively correlated, but they are not the same component. 
Snyder made four categories regarding the combination of pathway thinking and agency thinking. The combinations are pathway thinking and agency thinking low, pathway thinking low and agency thinking high, pathway thinking high and agency thinking low, and pathway thinking and agency thinking high (Snyder \& Lopez, 2007).

Individuals who have low pathway thinking and agency thinking have little confidence that they will achieve success in realizing their goals. Individuals with these characteristics sometimes also have a problem; they do not have a purpose in life. Low expectations have an impact on the overall life of an individual. Without the desire to act and plan, individuals can get depression. The feeling of depression comes because individuals think that they do not have the ability to achieve their goals. In addition, negative emotions can increase if individuals do not have the ability to define their goals clearly.

Individuals with low agency thinking and high pathway thinking are individuals who do not have enough mental energy to realize their plans. Individuals who are in this state will experience burnout. Many individuals who have low agency thinking look like doing something that can impress others. However, the individual remains at the same stage.

High hopes can make individuals gain various benefits when they are facing difficulties. In some life situations, individual steps often get obstacles by someone or something. However, individuals who have high hopes can think of alternative paths to achieve their goals and will directly apply the path that looks more effective. In conclusion, hope is a combination of mental agency thinking and pathway thinking that the function is to achieve goals. Both of these components called mental because hope is a process that constantly occurs in which the process includes what individuals think about themselves that has a connection with the goal. The thought by these individuals can influence real behavior.

\section{Hopes from Islamic Perspective}

Talking about hope from an Islamic perspective will use the Qur'an and the Hadith as its primary source. Hope comes from the word rajâ which means hope. Rajâ or hope desired by Islam is the hope addressed to Allah as the only One who is powerful in the earth, to obtain His forgiveness, obtain prosperity and happiness in this world and the hereafter (Sudirman et.al, 2019), and most importantly, hope the mercy and good pleasure of Allah.

Someone who hopes to get the pleasure and mercy of Allah and happiness in the world and the hereafter will certainly attempt to do actions that can realize their hopes. However, if someone is only hoping without going to try, then it is called daydream of something impossible to realize, or in the Arabic term tamanni (wishful thinking). Therefore, someone who hopes is also not allowed to give up if what he hopes is still not achieved, see Q.S. Yusuf/12: 87. 
Based on this verse, a Muslim is always encouraged to have hope. If he has no hope and easily discouraged, then he is among those who disbelieve. The hope must always exist, even when someone is facing death. Hope for the grace of Allah and His forgiveness. In the above verse, it can also conclude that hope is directly proportional to faith. If there is faith, there is hope and vice versa. If there is no faith, there will be no hope. Hope in Islam is not only belonging to certain people but also all humans. As a comparison, see (Yusuf et al., 2018); (Setiawan et al., 2018).

Rajâ or hope in practice must be accompanied by the practice of deeds ordered by Allah and away from what is forbidden by Him. Hope in Islam is also closely related to prayer because this hope is one important element in prayer. Hope to Allah can be very meaningful when a Muslim prays to Allah. Therefore, when praying, Muslims are always required to hope that their prayers will be granted, whether directly, replaced with better ones, or the hopes will be deferred until the End Times.

Ibn Taymiyyah, said; "Please know that there are three heart movers towards Allah: mahabbah (love), khauf (fear) and rajâ '(hope). The strongest of the three is mahabbah because love is the real goal. Love is something that is expected to continue to exist in the world and the hereafter. Different from fear, the fear will later disappear in the afterlife (for those who are in heaven). Even though mahabbah is the strongest, hope will strengthen it (Sylvén, 2020). If only mahabbah that is relied on by Muslims without hope in it, then the mahabbah will not mean anything. Because the purpose of mahabbah and hope is the same; to expect forgiveness (Suud, 2018)., pleasure, and mercy from Allah, as a comparison.

The hope that is built up for a Muslim to achieve goals comes from conscience, considered by the mind, and rely on the giver of hope itself, Allah, not only those that come from wishful thinking. Because not all dreams that arise in the Muslim mind can be a hope, but there must be a consideration first. So, even if hopes begin with dreams (Huebner, 2020), they must first be studied and considered. Does this hope can deliver to the pleasure and mercy of Allah or is it only because of the encouragement of his lust. If because of lust, then the main goal of his hope that is getting pleasure and mercy from Allah will not be achieved, see Q.S. al-Insyirah/94: 7-8.

Allah commands humans to always attempt earnestly for all the things they do. All efforts done in earnest will get a good result. However, humans must remember that the effort they do also must be accompanied by hopes that only addressed to Allah as the holder of control over all the efforts they do. In other terms, the work done by humans is referred to as endeavor. Thus, hope here has three essential elements: ikhtiar, tawakkal, and prayer.

1. Ikhtiar; or endeavor, comes from Arabic (ikhtiar), which means looking for better results. In terms, it means human efforts to meet the needs in his life, 
whether in material, spiritual, health, or even his future so that he can fulfill the life goals (Long, 2020). Everything can only be said as a true endeavor if it contains an element of goodness. The goodness meant here is the goodness according to Islamic shari' $a$, not merely goodness comes from the mind, custom, or public opinion.

The endeavor must be carried out seriously, wholeheartedly, and as maximum as possible in accordance with the abilities and skills of each individual, as mentioned in the Qur'an Q.S. al-Insyirah/94: 7-8 before. However, once again, if the endeavor failed, then a Muslim does not allow to despair. A Muslim must research the things they do, always be careful if they are looking for friends or partners who support the things they do and bring improvements in professional management. This is called an endeavor in Islam. Islam does not know the word despair because that will only make people do not want to try to do other good things. Islam continues to encourage humans to try hard. Even if the attempt fails, humans must be patient and keep trying.

2. Tawakkal; or surrender; means recumbency, entrust and represent. So, people who put their trust are those who surrender, entrust, and represent their affairs only to Allah. In term, tawakkal has several different meanings of salaf teacher; these definitions are:

1) Imam Ahmad bin Hambal, interpreted surrender as an activity of the heart, which means an action carried out by the heart, not something spoken by oral, not something done by a part of the body. Tawakkal is also not a science or knowledge (See al-Jauzi/ Tahdzib Madarijis Salikin, p. 337);

2) Ibn Qayyim al-Jauzi interpreted surrender as amaliyah (practice) and ubudiyah (servitude) of the heart. That interpretation can be done by relying on everything only to Allah, tsiqah towards Him, being under His protection, and being pleased with something that happened. Those things based on the belief that Allah will give everything that sufficiency for him by continuing to carry out causes or factors that lead him on something he is looking for, as well as hard efforts to be able to obtain it (al-Jauzi, 1975). When a Muslim realizes that everything that happens and experience by him is protection from his $R a b b$, surely he will also recognize that there is a Rabb who is almighty, most helpful, protective, and loving. And that is when he depended on Him. Reliance only on Allah is also called surrender. The verses relating to tawakkal include; Q.S. Al-Anfal: 61, 49; and Q.S. atThalaq/65: 2-3.

The conclusion of the above verse is that when a person relies on Allah, he will get an unexpected answer from Allah. The answer from Allah can be in the form of spaciousness, ease of all his affairs, a way 
out of all his problems, or even giving sustenance by Allah from the direction which he never expected before. In addition to the three verses above, there are still many other verses that explain the command to rely only on Allah. In connection with hope or raja, tawakkal is the second stage that must be carried out by a Muslim after ikhtiar (effort). After there is an effort, then he must be tawakkal (surrender). Surrender does not mean a hope without effort, because surrender will only be there after effort. And when someone forgets the tawakkal after endeavoring, he will fall and lead to despair (Zulaiha). In other words, the loss of effort means the loss of the essence of the surrender.

3. Duâ; the third stage of the rajâ process or hope is prayer. Prayer becomes the determinant of the realization of hope. In addition to endeavor and surrender that must exist in hope, there must also be prayer because prayer without effort is nonsense, while effort without prayer is vanity. Allah owns everything, and $\mathrm{He}$ is the only One who will grant all the requests of His servants, "Pray to Me (Allah), then I will grant your request."

However, it must also be noted that the answer to prayer will not be immediately granted or realized. There are three kinds of answers to the prayers that a Muslim makes to Allah; first, they are immediately granted. It is when a Muslim prays, then Allah answers the prayer immediately or in a short period. Second, Allah does not give what is in the prayer, but Allah replaces it with something far better because Allah knows what His servants know and do not know, as in Q.S. al-Baqarah/2: 216. Third, Allah will grant the prayers of someone in the hereafter and make it a saving practice in the hereafter, and this is truly an immeasurable reward (see Q.S. al-A'la/87: 17).

Prayer also has extraordinary powers that can move a person to do more to achieve his goals. In Islam, prayer is not just what someone says after he completed his worship, but the worship itself is already a prayer. That is why when someone performs worship, his heart will be calm and he feels like he wants to do it continuously because every word in the prayer is a remembrance that can calm the heart (Q.S. ar-Ra'd/13: 28).

Worship to Allah continuously, dzikr to Him all the time, ask forgiveness, and always prayer can make someone closer to Allah. He will feel he is in the protection and care of Allah, so that his conviction to get maghfirah (forgiveness) is getting stronger. He will feel pleased, tolerant, and feel calmer and peaceful in his life. Those are the three elements that found in hope from an Islamic perspective. Ibn Al-Wazir, in his very famous book, al-Awashîm wa al-Qawashîm, said that the hope of Allah's grace will always open the door of hope for a servant of Allah. It also will strengthen him in 
doing obedience, make him more enthusiastic in carrying out the practices of the sunnah, and he will immediately do good things (Ibn al-Wazir, 1990).

\section{CONCLUSIONS}

There are significant differences between the theory of hope from the West and the theory of hope from the East. The differences can be seen from the emphasis and the background of each theory. Furthermore, the theory of hope from Charles R. Synder relies on two concepts, agency thinking and pathway thinking.

The theory of hope from the West perspective has different emphases and backgrounds, while the theory of hope from Islam perspective already includes the components of hope expressed by the West. Hope in Islam is not only for things that are worldly or temporary but also for things that are $u$ khrawi (afterlife). Because Islam believes in the existence of the judgment day, while the West still doubts the existence of the afterlife after death, to account for all the deeds he did while still alive in the world.

Theories of hopes from the West limited due to the emergence of physiological or biological motivation. The study did not even cover spiritual motivation. While Islam, had already included spiritual motivation as part of human self-concept. Not only must fulfill physiological motivation but also spiritual motivation. The theory of hope introduced by Islam is far completest and complex because it does not just talk about why humans have to hope and to whom they have to hope. The theory also provided concepts that make humans easy to maintain and realize their hopes, through ikhtiar (effort), tawakkal (surrender) and pray to Allah, the possessor of all humanity. Therefore, it is necessary to have a better concept of hope in Islam, especially to enrich Islamic scientific treasures.

\section{REFERENCES}

Al-Jauzi. (1975). Arruh fi Kalam ala Arwahil Amwat wal Ahya' bidalail minal Kitab was Sunnah.

Bailey, T., Eng, W., Frisch, M., \& Snydert, C. (2007). Hope and optimism as related to life satisfaction. The Journal of Positive Psychology, 2, 168-175.

Baudrillard, J. (1996). The system of objects. Verso.

Chaer, M. T. (2016). Agama dan Psikologi; Antara Superioritas dan Inferioritas. AlMabsut: Jurnal Studi Islam dan Sosial, 10(1), 14.

Chaer, M. T., \& Febrianingsih, D. (2018). Positive Psychology: Personalities, Major Issues, Advantages and Disadvantages. Muaddib: Studi Kependidikan Dan Keislaman, 8(1), 20.

Chen, J., Huebner, E. S., \& Tian, L. (2020). Longitudinal relations between hope and academic achievement in elementary school students: Behavioral engagement as a mediator. Learning and Individual Differences, 78, 101824. https://doi.org/10.1016/j.lindif.2020.101824 
Dalai Lama. (2013). His Holiness the 14th Dalai Lama. Tulane University. https:/ / www2.tulane.edu/grads/speaker/dalai-lama.cfm

Fromm, E. (1952). Psychoanalysis and Religion. Philosophy, 27(103), 373-374.

Fromm, E. (1962). Beyond the Chains of Illusion: My Encounter with Marx and Freud. Continuum.

Hadi, Sutrisno (1980). Metodologi Research. Yayasan Fakultas Psikologi UGM.

Ibnu Al-Wazir. (1990). Zadul Ma"ad Bekal Perjalanan ke Akhirat terjemahan dari Kitab Mukhtasar Zadul Ma"ad. Pustaka Azzam.

Langlois, S., Pauselli, L., Anderson, S., Ashekun, O., Ellis, S., Graves, J.\& Compton, M. T. (2020). Effects of perceived social status and discrimination on hope and empowerment among individuals with serious mental illnesses. Psychiatry Research, https://doi.org/10.1016/j.psychres.2020.112855

Lewis Mumford. (1967). the Myth of the Machine (Vol. I): Technics and Human Development: Vol. I. Harcourt, Brace Jovanovich.

Long, K. N., Kim, E. S., Chen, Y., Wilson, M. F., Worthington Jr, E. L., \& VanderWeele, T. J. (2020). The role of Hope in subsequent health and wellbeing for older adults: An outcome-wide longitudinal approach. Global Epidemiology, 100018. https://doi.org/10.1016/j.gloepi.2020.100018

M. Suud, F. (2018). Pendidikan Kedamaian di Era Digital (Telaah Model Forgiveness dalam Psikologi Islam). Fikrotuna, 7(1), 694-716. https:/ / doi.org/10.32806/jf.v7i1.3170

Mahfud, Choirul (2006). Pendidikan Multikultural. Yogyakarta: Pustaka Pelajar

Marx, K. (1844). Economic E Philosophic Manuscripts of 1844. 81.

Moleong, Lexy, J. (2005). Metodologi Penelitian Kualitatif. Bandung: Remaja Rosdakarya

Setiawan, W., Suud, F. M., Chaer, M. T., \& Rahmatullah, A. S. (2018). Pendidikan Kebahagiaan dalam Revolusi Industri 4. Al-Murabbi: Jurnal Kependidikan dan Keislaman, 5(1). 3403/2530

Singarimbun, Masri dan Sofian Effendi (1989). Metode Penelitian Survey. LP3ES. Jakarta.

Shanahan, M. L., Fischer, I. C., \& Rand, K. L. (2020). Hope, optimism, and affect as predictors and consequences of expectancies: The potential moderating roles of perceived control and success. Journal of Research in Personality, 84, 103903. https:// doi.org/10.1016/j.jrp.2019.103903

Snyder, Lopez, \& Pedroti. (2001). Positive Psychology; the Scientific and Practical Explorations of Human Strengths. Sage Publications Inc.

Sudirman, S. A., Suud, F. M., Rouzi, K. S., \& Sari, D. P. (2019). Forgiveness and Happiness through Resilience. Al-Qalb: Jurnal Psikologi Islam, 10(2), 113-132.

Sylvén, I., Olsson, I., Hallböök, T., Rydenhag, B., \& Reilly, C. (2020). 'In the best case seizure-free'-Parental hopes and worries before and satisfaction after their child's epilepsy surgery. Epilepsy $\mathcal{E}$ Behavior, 110, 107153.

Widarto. (1990). Teknologi Harapan: Antara Harapan dan Kenyataan. Cakrawala Pendidikan. 
IJIEP: International Journal of Islamic Educational Psychology

Vol. 1, No. 1, 2020

Yusuf, M., Kahfi, D., Ibala, M., \& Chaer, M. T. (2018). Sabar dalam Perspektif Islam dan Barat. Al-Murabbi: Jurnal Kependidikan dan Keislaman, 4(2), 14. 